\title{
微小座面すべりに起因したボルト・ナット締結体の 微小ゆるみ挙動に関する有限要素法解析*
}

\author{
泉 聡志*1, 木村成 竹*2, 酒井信 介*1 $^{* 1}$
Small Loosening of Bolt-Nut Tightening System due to Micro Bearing-Surface Slip : Finite Element Method Study

\author{
Satoshi IZUMI*3, Masatake KIMURA and Shinsuke SAKAI \\ ${ }^{* 3}$ Department of Mechnical Engineering, The University of Tokyo, \\ 7-3-1 Hongo, Bunkyo-ku. Tokyo, 113-8656 Japan
}

\begin{abstract}
Bolt-nut tightening systems are widely used in mechanical structures since the disassembly for maintenance is easy without much cost. However, vibration induced loosening has been unsolved subject. In this paper, we have paid attention to the mechanisms of small loosening process due to micro bearing-surface slip in the framework of the three-dimensional finite element method (FEM). Results show good agreement with Kasei's experimental results. It was found that early-stage nut rotation obtained by the experiments originates from bolt-nut simultaneous rotation induced by tightening torsion of bolt and does not correspond to the loosening rotation. Therefore, loosening rotation must be defined by the relative rotational angle of nut with respect to bolt. It was also found that the small loosening initiates when the vibrational force reaches about 50 to $60 \%$ of that bearingsurface slip occurs. It is necessary to pay attention to the contact state of both bearing surface and thread surface for the consideration of loosening of bolt-nut tightening systems. Contact states are classified into three kinds of states, that is, complete slip involving no sticking region, micro slip involving no ever-sticking region over a vibration cycle, and localized slip involving ever-sticking region over a vibration cycle. A total of nine kinds of contact states are defined by the combination of the bearing surface and thread surface. It is also found that loosening rotation can proceed when micro slip or complete slip occurs at both thread and bearing contact surfaces.
\end{abstract}

Key Words: Finite Element Method, Bolt, Nut, Loosening, Contact Problem, Machine Element, Bolted Joint

\section{1. 诸}

ボルト・ナット締結は, 取り付け・取り外しのし やすさと低価格なことから幅広く使用されている ${ }^{(1)}$. しかしながら, ボルト・ナット締結体のゆるみの問題 は, 現在もなお課題として残っており，ゆるみに起因 した事故が多く起こっている.

前報 (2) (3) で筆者らはねじ山の螺旋形状の接触を考 慮した三次元有限要素法により, ボルト締結体の軸直 角方向荷重によるゆるみの解析を行い，山本・賀勢ら の実験 (4) と非常に良い一致を示すことを示した．また， 賀勢ら ${ }^{(5)}$ ，Paiら ${ }^{(6)}$ (7)によって提案されている座面 すべり以前で生じる微小なゆるみ（微小座面すべりに よる微小ゆるみ $\left.{ }^{(8)}\right)$ が進行することも見出した.こ のような微小なゆるみは座面すべりによるゆるみと異

\footnotetext{
* 原稿受付 2005 年 8 月 5 日.

*1 正員, 東京大学大学院工学系研究科(- $1113-8656$ 東京都文 京区本郷 7-3-1).

*2 学生員, 東京大学大学院工学系研究科.

E-mail : izumi@fml.t.u-tokyo.ac.jp
}

なり，極めて低速で進行するため検出が困難である.

一方, 座面すべりは数サイクルで大きな軸力低下を伴 うため検出が容易であるが，現在の設計でこのような 現象が起こるとは考えにくい，産業界で生じているゆ るみの問題の中には，この微小ゆるみに起因している ことが少なくないと考えられる. しかしながら，実験 的にも理論的にもその詳細はわかっていない. 工学的 見地より, 微小ゆるみに対する評価法の構築が急務で あると考えられる.

本論文では，座面すべり以前に生じる微小なゆる みに焦点を当て，そのメカニズムを有限要素法により 解明する. 結果は, 最近の賀勢らの実験結果 ${ }^{(8)}$ と非 常に良い一致を示し，本論文のモデルが現実の現象を よく再現していることを示す. 最後にボルト・ナット 締結体のゆるみのメカニズムに対する新しい理論体系 を提案する.

\section{2. 解 析 手 法}


賀勢ら ${ }^{(8)}$ のボルト・ナット締結体の軸直角方向荷 重のゆるみ試験を模擬し, 図 1 のような M10 ボル ト・ナットのグリップ長さ $28 \mathrm{~mm}$ の有限要素モデルを 作成した. 有限要素法モデルの詳細は前報 ${ }^{(2)}{ }^{(3)}$ にも 示した.

ナットは六角をモデリングせず外径を 2 面幅の基 準寸法である $17 \mathrm{~mm}$ として作成した. 被締結体のねじ 穴径については実験に合わせて $12 \mathrm{~mm}$ として作成した. 被締結体については可動板のみをモデル化し下面の $y$, $z$ 方向変位を拘束し, $x$ 方向端面の $x$ 方向変位をカップ リングし， $300 \mathrm{~N}, 500 \mathrm{~N}, 600 \mathrm{~N}$ の外力でそれぞれ加振す ることでゆるみを発生させた。

締結力はナットを締め付けることで発生させた. その際, 第一荷重ステップでボルト・ナットのねじ面 が接触した状態から, ナット外周の節点に周方向に $1.284 \mathrm{~mm}$ の強制変位を与え, その後第二荷重ステップ においてナット外周の節点への強制変位を除荷するこ とにより, 締結力 $10 \mathrm{kN}$ を発生させた. 前報 (2) (3) の 座面すべりの解析では締め付けによるねじれは座面す ベりが一度起こってしまえば解消されてしまうが, 本 解析では十分に解消されない場合もあるため, モデル の正確性を増すために締め付け過程を考虑した解析を 行った.

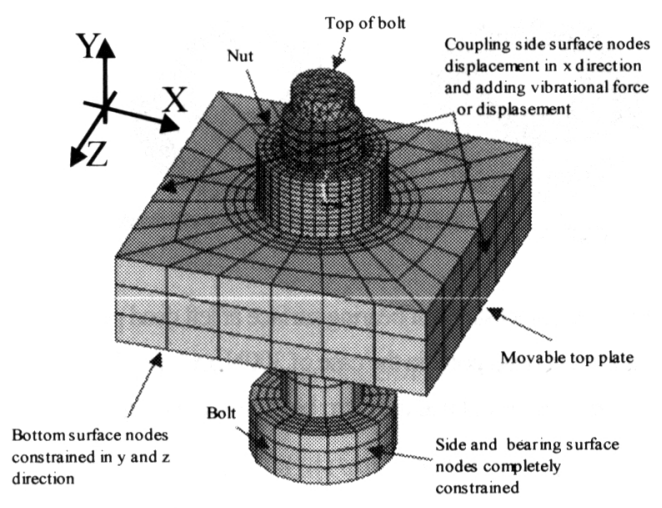

Fig. 1 Finite element model for loosening of threaded fastener subjected to quasi-static transverse load.

解析には汎用有限要素法解析ソフト ANSYS 8.0 を 用いた. 賀勢らの実験の加振周波数が十分小さいとし て準静的解析を行った. 接触アルゴリズムはクーロン 摩擦を再現したペナルティー法を用い，ボルト・ナッ トねじ面間とナット座面被締結体間に接触を定義した. 賀勢らによる実験では $\mathrm{MoS}_{2}$ 潤滑が採用され, 摩摖倸
数は 0.1 程度であると予測されるため, ねじ面, 座面 ともに摩擦係数 0.1 とした.

\section{3. 解 析 結 果}

図 2 に各並進荷重の計算結果の最終サイクル (22 サイクル）における並進力一並進変位の関係を示す. また, 図 3 には荷重が一番大きい $600 \mathrm{~N}$ の時の接触状 態を示す. 図 4 にはボルト軸のねじれ角を示す。攼じ れはボルト上端の $0^{\circ}, 90^{\circ}, 180^{\circ}, 270^{\circ}$ の 4 点に おける固定された座標系に対寸る回転角の平均值を用 いた，本論文では，ねじれおよび回転角の值は $y$ 軸正 回転方向を正として表すこととする. ナットを締め付 ける際におよそー $0.23^{\circ}$ のねじれがボルト軸に生じて いる.

図 5 にナット回転角の進行を実験結果 ${ }^{(8)}$ と合わせ て示す.ナット回転角はナット上面（座面の反対側）

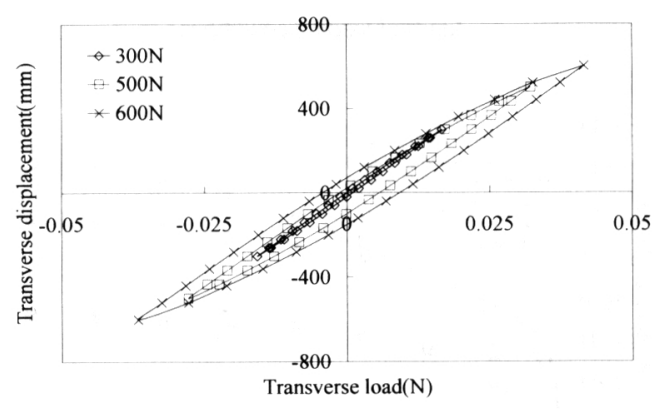

Fig. 2 Relationships between transverse load and transverse displacement under three kinds of loading conditions

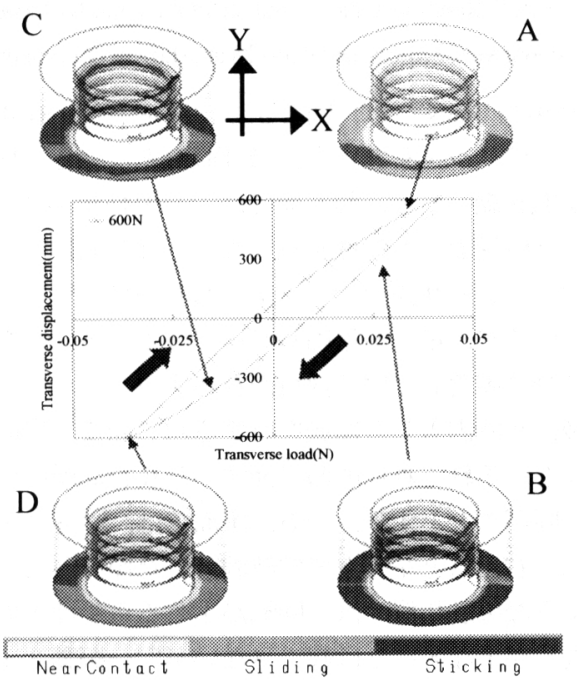

Fig. 3 Evolution of contact state during loosening process. 
の $0^{\circ}, 90^{\circ}, 180^{\circ}, 270^{\circ}$ の 4 点における空間に固 定された座標系に対寸る回転角の平均值を用いた。ま た，解析では力による加振でゆるみを発生させたが, 加振力に対応寸る変位振幅は $0.016,0.030,0.039 \mathrm{~mm}$ と 実験にほぼ対応した值となった.ナットの回転角は賀 勢らの実験結果と良い一致を示していることがわかる.

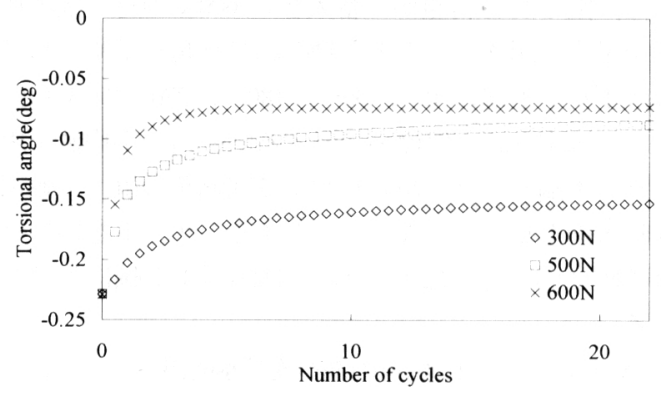

Fig. 4 Torsional angles of the top of bolt under three kinds of loading conditions

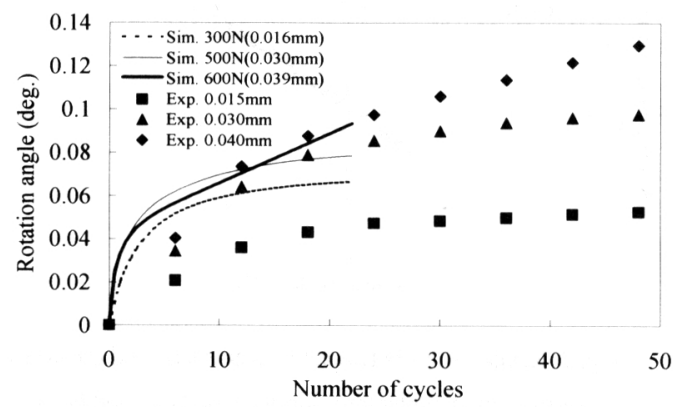

Fig. 5 Rotation angles of nut under three kinds of loading conditions. Experimental results are shown for comparison.

加振力 $300 \mathrm{~N}$ では，図 2 より，並進変位一荷重曲線 がヒステリシスを持たず，ほぼ直線となった，接触面 の状態を調べると，ねじ面では，一振動サイクルにお いて常時固着した領域を有しながら部分的にすべりが 発生している状態（ナット第一ねじ山ではすべりを生 じているが，第二〜第四ねじ山では 1 サイクルを通じ て完全に固着している部分が存在する）となっている. 以後, 常時固着した領域を有するねじ面及び座面のす ベりを，それぞれ局所ねじ面すべり及び局所座面すべ りと呼ぶこととする。，一方，座面では，図 6に示すよ うに, 右死点と左死点で常時固着した領域がない. こ のような接触状態では，回転が生じる可能性がある. 以後, 完全なすべりは起こさないが, 一振動サイクル において常時固着した領域がないねじ面，座面のす心゙
りをそれぞれ，微小ねじ面すべり，微小座面すべりと 呼ぶこととする.

結果, 礼じ面で常時固着領域があるため，ゆるみ は進行しないと考えられる。しかしながら，図 5 に示 すように，ナットの回転角はわずかに進行している. これは，締め付け時のボルトのねじれを駆動力に，ナ ットとボルトのねじ面が固着しながら同時に回転（座 面は微小座面すべり状態）しているために生じる回転 角であり（以後同時回転と呼ぶ），ゆるみには直接関 係しない. 図 7 にボルト軸に対するナットの相対回転 角を示寸．実験では，相対回転角は計測されていない が，解析より加振力 $300 \mathrm{~N}$ の場合，初期の 1, 2 サイク ルでゆるみと逆方向の相対回転が生じ，その後相対回 転は全く進行していないことがわかる．図 8 に軸力の 変化を示す.ただし, 相対回転角と対応付けるため, 下向きを正（軸力増加）としている．他の荷重条件の 場合も含女て，軸力の変化と相対回転角の傾向はほほ 一致し，相対回転角が回転ゆるみの指標として適当で あると考えられる. よって, 加振力 $300 \mathrm{~N}$ では相対回 転と軸力の結果より，ゆるみは進行していないと結論 できる。

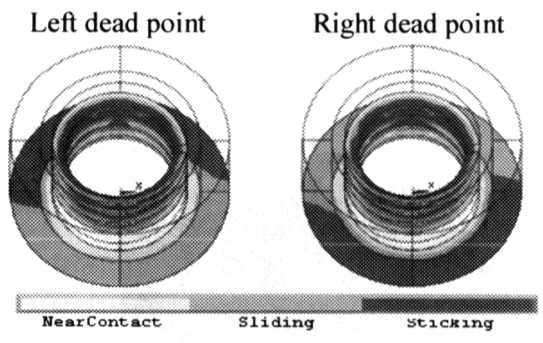

Fig. 6 Contact states of bearing surface at left dead point and right dead point in the case of $300 \mathrm{~N}$ analysis. The behavior is defined as micro bearing-surface slip.

この最初の 1,2 サイクルの相対回転はボルト軸のね じれ解消のために生じると考えられる，座面では微小 座面すべり状態にあり, すべてのねじ面では固着領域 がない完全すべりを生じ，締まり方向に相対回転が生 じている.この初期の締まり方向の相対回転は，加振 力 $300,500,600 \mathrm{~N}$ の全てのケースで生じている.ここ で，ねじ面，座面の固着領域が存在しないすべりを， 完全ねじ面すべり，完全座面すべりと呼ぶこととする 後者は単に座面すべりとも呼ばれる.

まとめると，加振力 $300 \mathrm{~N}$ のケースでは，最初の 1 , 2 サイクルにおいてはボルトのねじれに起因して，座 面では微小座面すべり, ねじ面では完全ねじ面すべり 
が起こり, 締まり方向の相対回転が生じる，その後, ねじ面が局所㸚じ面すべりの状態になるため, 相対回 転（ゆるみ回転）は生じない，しかしながら，座面が 微小座面すべりを起こすことによって，ボルト軸のね じれを駆動力にナットとボルトの同時回転が生じ，ナ ットは回転する．同時回転は妨じれが小さくなると， ほとんど起こらなくなる.

加振力 $500 \mathrm{~N}$ では図 2 の並進変位一荷重曲線にわず かにヒステリシスが生じる. 接触面の状態を調べると， $300 \mathrm{~N}$ と異なり，第一ねじ山から第三ねじ山まではね じ面完全すべりが，第四妨山゙山では微小ねじ面すべり が生じている．座面の接触状態は，300N と同様，微 小座面すべりの状態にある.このような，ねじ面の接 触状態の違いにより，300N の場合と比較して，岡性 の変化が現れ，変位一荷重曲線に折れ曲がりが生じた ものと考元られる. 図 7, 図 8 の相対回転角, 軸力変 化より，ゆるみはごくわずかであるが発生していると 考えられる $\left(4.6 \times 10^{-5 \circ}\right.$ /cycle $)$ ，最初の数サイクルの 相対回転及びその後のナット回転は $300 \mathrm{~N}$ と同様, ボ ルト軸のねじれの解消によるものと考えられる.

加振力 $600 \mathrm{~N}$ では，図 2 の並進変位一荷重曲線に明 確なヒステリシスが現れる. 図 3 の接触状態より, 曲

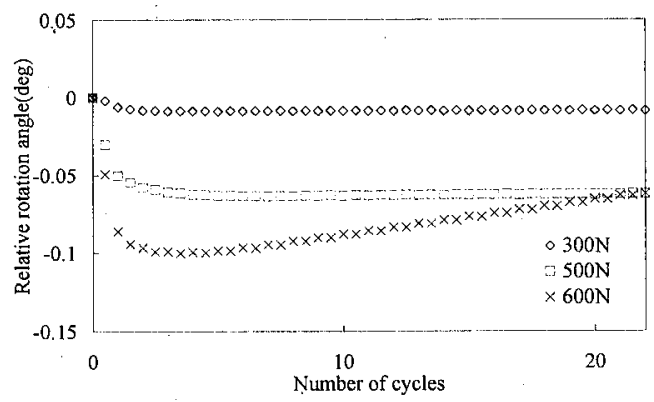

Fig. 7 Relative rotation angles under three kinds of loading conditions

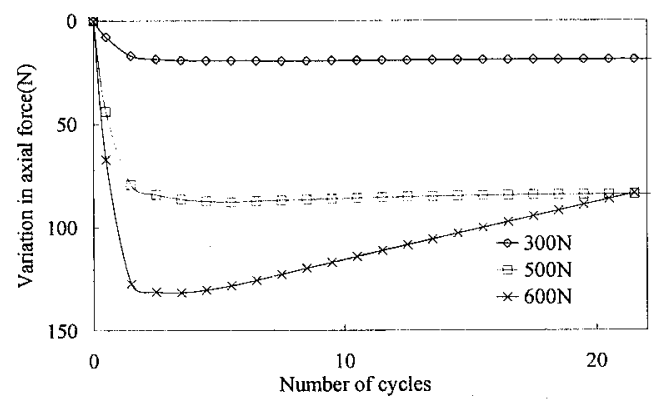

Fig. 8 Variation in axial forces under three kinds of loading conditions
線の勾配が変化する $\mathrm{A}$ 点では；ねじ面の完全す心゙り が発生していることがわかる。このとき座面の接触状 態は手前側 $(z$ 軸正方向) に固着域が存在し，奥側は 完全にすべっている. 右死点を過ぎ加振力の減少過程 である B 点では，座面のほぼ全面が固着し，ねじ面 は，第一から第三ねじ山が固着している．その後，C 点では逆向きに加振力が加えられ，权じ面での寸べり が起こり始める．ねじ面での固着域は次第に座面から 離れた水じ山の方八移動していき，D点において完全 ねじ面すべりが発生する，左死点側では座面の固着域 は奥側に存在する. A 点と D 点の座面の状況を比較 すると図 6 同様，1サイクルを通じて見ると常時固着 している部分が存在しない微小座面ずべが生じてい ることが分かる。また，図4に示寸ように，ボル卜軸 のねじれはねじ面完全すべりのため数サイクルで解消 され，抢よそー $0.075^{\circ}$ で停留する. この值は摩擦力 とボルトのねじれカが釣り合う角度と考えられる.ボ ルト軸のねじれが解消されることにより, 同時回転は $300 \mathrm{~N}$ の場合と比較してほとんど起こらない。また, 図 7,8に，相対回転角と軸力の低下を示す.これらの 二つの傾问はほぼ一致し,ゆるみ回転がほぼ一定の速 度 $\left(2.3 \times 10^{-3}\right.$ 。 $/$ cycle $)$ で進行することがわかる。

\section{4. 考察}

4-1 実験結果との比較 図 5 より, 実験結果 は振幅 $0.040 \mathrm{~mm}$ でナット回転角が一定速度で進行し ている．振幅 $0.015 \mathrm{~mm}$ および $0.030 \mathrm{~mm}$ においてはナ ット回転角がゆるやかに進行し, 停留する.この初期 のナット回転は，締め付けによるボルト・ナットの同 時回転に起因したもので，ゆるみとは関連しない，実 験結果と計算結果の比較功, ナット回転角の定性的 な傾向のみならず，定常的にゆるみが進行する臨界荷 重 $(0.030 \mathrm{~mm}(500 \mathrm{~N})$ の近辺) がよく一致していること がわかる。

本論文ではねじ面, 座面ともに摩擦保数を 0.1 とし たが，MoS 潤滑を用いた実験における正確な摩擦係 数が求まっているわけではなく, 完全に定量的な比較 は難しいと考えられる．また，実験における初期の 5 サイクル程度に限っては，初期のセッディングの乱れ を含むため，測定精度的に有意な結果が得られていな い可能性があり，比較は困難であると考えられる.

4:2 加振力とゆるみ速度の関係 加振力とゆ るみ速度の関倸を図 9 に示寸. ただし，加振力は座面

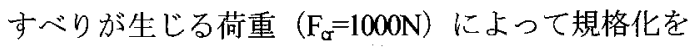
行っている. 
図 9 より, 微小ゆるみは座面すべりが起こる荷重 のおおよそ $50 \%$ から 60\%程度の荷重で生じ, 荷重が大 きくなる程ゆるみ速度が非線形に大きくなることがわ かる. なお，本解析条件でのゆるみは，ねじ面完全す べりと座面微小すべりの状態で進行する. 従来のボル ト・ナット締結体の設計においては, 座面すべりが生 じる荷重が設計に用いられていたが，十分なゆるみ対 する安全裕度を確保するためには, 座面すべりが生じ る荷重のおおよそ半分の值を設計に用いる必要がある と考えられる. また，ゆるみ角は，F/ $\mathrm{F}_{\alpha}=1$ となった 座面すべり時の $0.25^{\circ}$ / cycle と比較して非常に小さい.

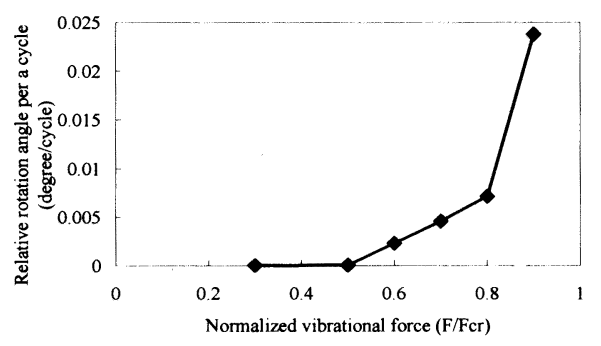

Fig. 9 Dependence of relative rotation angle per a cycle on normalized vibration force $\left(\mathrm{F} / \mathrm{F}_{\mathrm{c}}\right)$

\section{4・3 楴付によるボルト軸ねじれの坛霜の考察} 本論文では実験との比較のため, 締め付け解析を行っ た後に, ゆるみ解析を実施した. ここで, 締め付けの ねじれが及ぼす影響を考察するために, 前報同様, ナ ットの座面が被締結体可動板に接触した状態からわず かに下方に移動させ, ナット座面と被締結体を初期干 渉させて締結力を発生させたモデルについて, ゆるみ 解析を行った.

このときのナット回転の進行を図 10 に示寸. 図 5 と異なり, 初期の大きなナット回転が見られず, $300 \mathrm{~N}, 500 \mathrm{~N}$ ではほとんどナット回転は進行していない. $600 \mathrm{~N}$ の場合, 一定速度でナット回転が進行する.こ の進行速度は，締め付けによるねじれを考慮したモデ

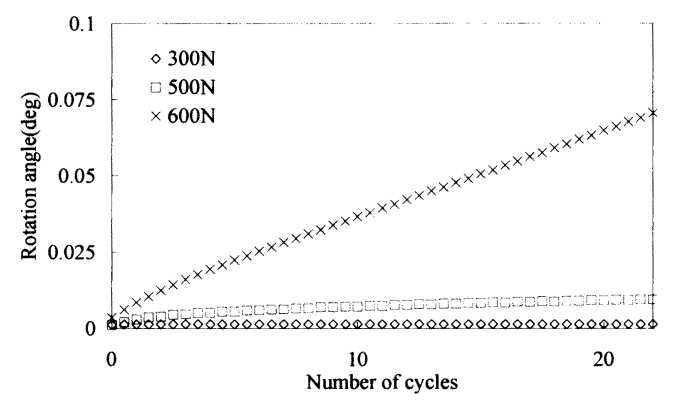

Fig. 10 Rotation angles of nut without tightening process
ルと同じであった．図 5 と図 10 の傾向を比較すると， 初期の傾向の違いはあるが，10 サイクル以降の傾向 は同一である. しかしながら, 図 10 の結果は実験結 果と大きく異なり, 実験結果とのナット回転の比較の ためには, 締め付け時のねじれによる同時回転を考慮 することが重要であることが示された. しかしながら， 実用的にはゆるみ速度が重要であるため, 有限要素法 で締め付け過程を省略しても評価は可能であると考え られる.

もちろん, ナットの回転角とゆるみ回転は異なる ため, 実験においても相対回転を測定する必要がある と考えられる.

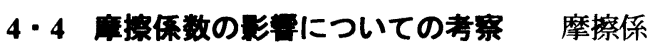

数の結果への影響を調べるため, 摩擦係数を 0.15 と して同様の解析を行った. 締結力は締め付けを行うこ とにより発生させた. 図 11 にナットの回転角, 図 12 に相対回転角を示す. ナットの回転角は，加振力が小 さければ大きくなるという結果となった。 これは初期 のボルトのねじれによる同時回転の影響であり, ねじ 面でのすべりが少ない低加振力のほうが，ねじ面同士

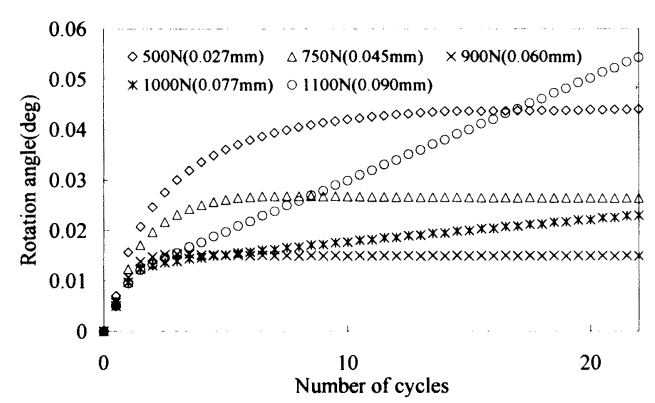

Fig. 11 Rotation angles of nut under various loading conditions in the case of friction coefficient of 0.15

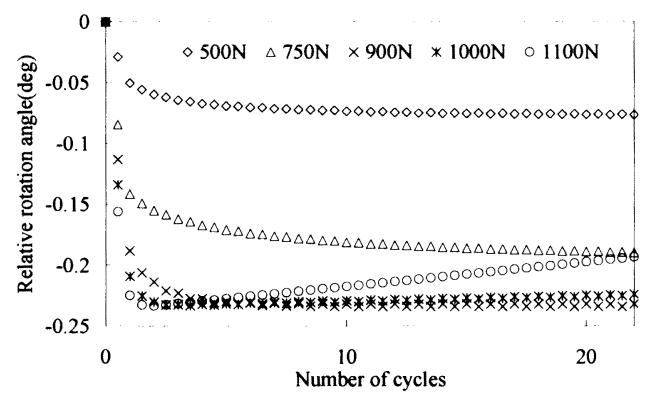

Fig. 12 Relative rotation angles of nut under various loading conditions in the case of friction coefficient of 0.15 
が固着しているため，長期にわたり，同時回転が起こ るためと考えられる。しかしながら，実際にゆるみが 進行するのは, 加振力が $1000 \mathrm{~N}$ 以上の場合のみと考 えられる. また，加振力 $900 \mathrm{~N}$ の場合は完全ねじ面す ベりが生じるにもかかわらず，ゆるみは進行しなかっ た. これは座面で微小座面すべりが起こらず, 局所座 面すべりの状態にあるためである. 摩擦係数 $\mu=0.1$ の ケースと異なり, 微小座面すべりがねじ面完全すべり より後に起こっている.ゆるみ速度の並進力依存性を 摩擦係数 $\mu=0.1,0.15,0.20$ の 3 ケースの場合についてプ ロットしたものを図 13 に示す. 摩擦係数が大きくな っても，座面すべりが生じる並進力の $50 \%$ から $60 \%$ 程 度の並進力で微小座面すべりによる微小ゆるみが生じ る. また，ゆるみ速度は摩擦係数に大きく依存するこ とがわかる.

\section{5 新しいゆるみ機推の理詥の提宋 従来の} 山本ら ${ }^{(4)}$ の理論は, 完全座面すべりのみが考慮され ているが，座面すべり以前の現象に着目すると，す心゙ りをねじ面と座面に分けて議論する必要がある。また， 座面，ねじ面のそれぞれの接触状態について，固着領 域がなくなる完全すべり，完全すべりは起こさないが 常時固着領域がない微小すべり, 常時固着領域が存在 する局所すべりの三通りに分類できる．整理すると， 接触状態は表 1 に示すように，九通りに分類される.

前報 (2) (3) の完全座面すべりの解析では, 表 1 の 一ス1のみを取り扱い，大きくゆるみが進行すること を示した．座面すべりが生じているが，ねじ面が完全 すべりを起こしていない状況も摩擦係数などの条件に よっては生じると考えられる. しかしながら，本論文 ではケース 2 とケース 3 は起こらなかった. ケース 2 はねじ面の微小すべりにより，ゆるみは進行すると考 えられる.ケース 3 は，ねじ面が回転しないため，ゆ るみは進行しないと考えられる. ケース 1 とケース 2

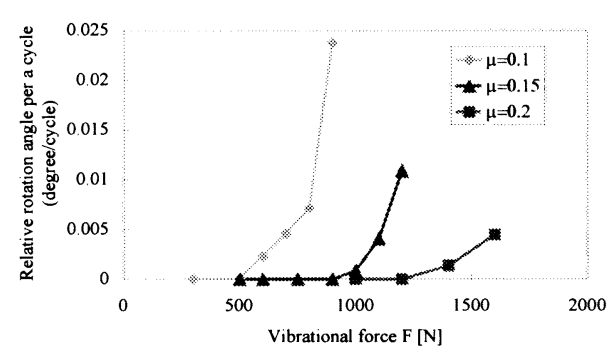

Fig. 13 Dependence of relative rotation angles on vibrational force under three kinds of friction coefficient $(\mu=0.1,0.15,0.2)$.
を合わせて完全座面すべりによるゆるみと総称するこ ととする.

座面が微小すべりを起こし，ねじ面が完全すべり を起こすケース 4 は, 摩擦倸数 $\mu=0.1$, 荷重 $\mathrm{F}=600 \mathrm{~N}$ で 行った解析に対応し，ゆるみは進行している. 座面, ねじ面ともに微小すべりが生じるケース 5 は, 摩擦係 数 $\mu=0.1$, 荷重 $\mathrm{F}=500 \mathrm{~N}$ で行った解析に対応し，ゆるみ はごくわずかに進行している. 座面が微小すべり，ね じ面が局所すべりのケース 6 は, $\mu=0.1, \mathrm{~F}=300 \mathrm{~N}$ の解析 に対応し，ナットの同時回転は起こるが，ゆるみは進 行しない. ケース 4 とケース 5 を合わせて微小座面す べりによる微小ゆるみと総称することとする。このゆ るみのモードは, 進行速度が非常に小さいため, 従来 の設計ではほとんど考慮されてこなかった. しかしな がら，高サイクル振動を受ける締結体においては低速 でも定常的に進行し, 軸力の低下を引き起こし, 完全 座面すべりによるゆるみへと発展するものと考えられ る.

座面が局所すべり，ねじ面が完全すべりのケース 7 は， $\mu=0.15, \mathrm{~F}=900 \mathrm{~N}$ の解析に対応し，ゆるみは進行し ない，座面が局所すべり，ねじ面が微小すべりのケー ス 8 は, $\mu=0.15, \mathrm{~F}=750 \mathrm{~N}$ の解析に対応し, ゆるみは進 行しない. 荷重が十分小さいケースはケース 9 に相当 し，ゆるみは進行しない.

このように，ねじ面と座面の両方の接触状態につ いて考えることがボルト・ナット締結体のゆるみを考 えるためには必要である．従来は座面すべりのみに焦 点が当てられてきたが，ねじ面すべり，特に完全ねじ 面すべりについて考慮したゆるみに対する設計が不可 欠である.

Table 1 Relation between contact states and loosening. Contact states are classified into nine kinds of states.

\begin{tabular}{|c|c|c|c|c|}
\hline & \multicolumn{3}{|c|}{ Bearing surface } \\
\hline & & $\begin{array}{c}\text { Complete bearing- } \\
\text { surface slip }\end{array}$ & $\begin{array}{l}\text { Micro bearing- } \\
\text { surface slip }\end{array}$ & $\begin{array}{c}\text { Localized bearing- } \\
\text { surface slip }\end{array}$ \\
\hline \multirow{3}{*}{ 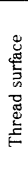 } & $\begin{array}{l}\text { Complete thread } \\
\text { surface slip }\end{array}$ & $\begin{array}{l}\text { casel loosening } \\
\text { Previous report }\end{array}$ & $\begin{array}{l}\text { case4 loosening } \\
\mu=0.1, \mathrm{~F}=600 \mathrm{~N} \\
\mu=0.15, \mathrm{~F}=1000 \mathrm{~N}\end{array}$ & $\begin{array}{l}\text { case7 no loosening } \\
\mu=0.15, \mathrm{~F}=900 \mathrm{~N}\end{array}$ \\
\hline & $\begin{array}{l}\text { Micro thread- } \\
\text { surface slip }\end{array}$ & $\begin{array}{l}\text { case2 (loosening) } \\
\text { (no analysis) }\end{array}$ & $\begin{array}{l}\text { case } 5 \text { loosening } \\
\mu=0.1, \mathrm{~F}=500 \mathrm{~N}\end{array}$ & $\begin{array}{l}\text { case8 no loosening } \\
\mu=0.15, \mathrm{~F}=750 \mathrm{~N}\end{array}$ \\
\hline & $\begin{array}{l}\text { Localized thread } \\
\text { surface slip }\end{array}$ & $\begin{array}{l}\text { case3 (no loosening) } \\
\text { (no analysis) }\end{array}$ & $\begin{array}{l}\text { case6 no loosening } \\
\mu=0.1, \mathrm{~F}=300 \mathrm{~N}\end{array}$ & $\begin{array}{l}\text { case9 no loosening } \\
\text { small load }\end{array}$ \\
\hline
\end{tabular}

5. 結

言

三次元有限要素法解析により, ボルト・ナット締 結体の微小座面すべりに起因する微小なゆるみの発生 メカニズムを明らかにした.

微小座面すべり起因のゆるみによるナットの回転 角は賀勢らの実験と良く一致した. 実験で測定されて 
いる初期のナット回転は, 締め付け時のボルトのねじ れを駆動力とした, ナットとボルトの同時回転に起因 しており，ゆるみ回転とは異なることがわかった。. るみ回転は，ナットとボルトの相対回転で定義される べきである. また，微小座面すべりが生じる荷重は， 座面すべりが生じる荷重のおおよそ 50〜60\%であるこ とがわかった.

ボルト・ナット締結体のゆるみの考察のためには, 座面とねじ面の両方の接触状態に着目寸る必要がある. 接触状態は，固着領域が存在しない完全すべり，振動 1サイクルにおいて常時固着している領域が存在しな い微小すべり，振動 1 サイクルにおいて常時固着して いる領域が存在する局所すべりの三種類に分類され， 座面とねじ面の組み合わせで，合計九種類の接触状態 が定義される．ねじ面・座面の両方共に微小すべりも しくは完全すべりを起こすと，ゆるみ回転が進行する ことがわかった.

$$
\text { 謝辞 }
$$

本研究をすすめるにわたって, 信州大学工学部機 械システム工学科賀勢晋司先生には実験データの提供 と大変有意義な助言を頂いた。ここに謝意を表する.

\section{文}

(1) Yoshimoto I., editor, Points of the Design of Threaded Fastener, (1992), p. 13, Japanese Standards Association.

(2) Izumi S., Yokoyama T., Iwasaki A. and Sakai S., Threedimensional Finite Element Analysis on Tightening and Loosening Mechanism of Bolted Joint, Transactions of the Japan Society of Mechanical Engineers, Series A, Vol. 71, No.702 (2005), pp. 204-211.

(3) Izumi S., Yokoyama T., Iwasaki A. and Sakai S., Threedimensional Finite Element Analysis of Tightening and Loosening Mechanism of Threaded Fastener, Engineering Failure Analysis, Vol. 12 (2005), pp.604-615.

(4) Yamamoto A and Kasei S., Investigation on the Self-loosening of Threaded Fastener under Transverse Vibration -A Solution for Self-loosening Mechanism-, Bulletin of Japan Society of Precision Engineering, Vol. 43, No. 4 (1977), pp. 470-475.

(5) Kasei S., Ishimura M. and Ohashi H., On Self-loosening of Threaded Joints in the case of Absence of Macroscopic Bearing-surface Sliding-Loosening Mechanism under Transversely Repeated Force, Bulletin of Japan Society of Precision Engineering, Vol. 54 (1988), pp. 1381-1386.

(6) Pai N. G. and Hess D. P., Three-dimensional Finite Element Analysis of Threaded Fastener Loosening due to Dynamics Shear Load, Engineering Failure Analysis, Vol. 9 (2002), pp. 383-402.

(7) Pai N. G. and Hess D. P., Experimental Study of Loosening of Threaded Fastener due to Dynamics Shear Loads, J. Sound and Vibration, Vol. 253 (2002), pp. 585-602.

(8) Kasei S., Yoshida W, Ishibashi H. and Okada M, Bearing Surface Slip and Self-loosening of Threaded Fasteners (Consideration on the Case of Minute Slippage), Proceedings of the Mechanical Engineering Congress, Vol. 4, 233-234, 2004 Japan. 